\title{
ETHICAL CONSUMERS IN GREECE: WHO ARE THEY?
}

\author{
Antonia DELISTAVROU ${ }^{1}$, Hristo Katrandjiev ${ }^{2}$ and Irene TILIKIDOU ${ }^{3}$ \\ ${ }^{1}$ TEI of Thessaloniki, Department of Business Administration, P.O. Box 141, \\ Thessasloniki, 57400, Greece, Tel: +30 2310 013242, \\ Email: delistavrou@yahoo.com \\ ${ }^{2}$ University of National and World Economy, Department of Marketing \\ and Strategic Planning, Student Town, Sofia, 1700, Bulgaria, \\ Email: hristkat@yahoo.com \\ ${ }^{3}$ TEI of Thessaloniki, Department of Business Administration, P.O. Box 141, \\ Thessasloniki, 57400, Greece, Email: irene.tilikidou@gmail.com
}

\begin{abstract}
The paper presents a segmentation on the basis of the overall ethical consumption concept for the first time in Greece. Four segments were identified: Ethical Consumers (18.09\%), Boycotters (20.48\%), Ecological Consumers (27.86\%) and Conventional Consumers (33.57\%). The Ethical Consumers' segment consists of well educated citizens, who adopt all ethical behaviours more frequently. These consumers were found to be more confident they can control politics, less materialists, most attracted by postmaterialist goals, as well as less sceptical towards ethical products and less indifferent about ethical consumption issues. This segment may be considered as attractive enough to be targeted by business and non-profit organisations.
\end{abstract}

Keywords: ethical consumption; segmentation; ethical consumers; ethical unconcern; materialism/postmaterialism; policy control; demographics.

JEL Classification: $\mathrm{M}_{31}$

\section{Introduction}

Ethical consumption refers to a concept of consumer behaviour that is influenced by ethical criteria such as caring not only for the self of the individual, who performs the behaviour, but for the others too, for fairness and for the welfare of the society in general [Harrison et al., 2005]. Of course, there is an undisputed rule within the marketing community: any kind of consumer behaviour should be adopted by a sizeable enough share of consumers in order to be financially 


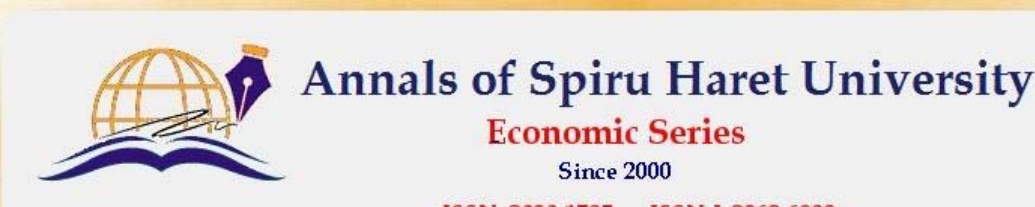

ISSN: 2393-1795 ISSN-L:2068-6900

Issue 3/2017

interesting, competitive and effective. Would and could consumer markets be segmented on the basis of ethical criteria? Is there any sizeable enough segment of ethical consumers or there are so few of them that should be viewed as a niche market? Further, which is the overall content of ethical consumption, its types and antecedents that might hopefully throw light on the profile of ethical consumers?

Tallontire et al. (2001) proposed three types of ethical consumerism, namely positive, negative and consumer action, in an effort to categorise all possible relevant activities in a manageable way. The later form (consumer action) has been later named "discursive" by Micheletti et al. (2005). The positive type concerns the choice of ethical products or service (e.g. eco-efficient products, organics, fairtrade products, etc.), as well as other ecological activities such as reuse, repair and recycle (3Rs). The negative type concerns the boycotting or consumers' remit from particular products or firms. The discursive type refers to a number of contemporary cultural actions of individuals using mostly digital means in order to share information about consumption practices. As the literature research indicated, each type and form of the overall concept of ethical consumption has been customarily examined separately from the other types. In fact, there have been just few in number exploratory attempts to examine the several aspects and types of ethical consumption [e.g. Carrigan \& Attalla, 2001; Baek, 2010; Delistavrou \& Tilikidou, 2012].

The aim of this project is to attempt a segmentation of the Greek market on the basis of all three types of ethical consumption and describe, in terms of demographic, attitudinal and psychographic characteristics, the segment of Ethical Consumers in Greece, in as many details as possible.

\section{Literature Review}

Positive ethical buying has been examined under various terminologies regarding the main dependent variables, such as socially conscious consumption [Pepper et al., 2009], buycotting [Neilson, 2010; Carfagna et al., 2014], positive buying [Koos, 2012], conscious consumption [Carr et al., 2012], positive ethical consumption [Delistavrou \& Tilikidou, 2012], political consumption [Copeland, 2014]. The aspect of ecological behaviours gained most of the research attention while very limited studies focused on purchasing fair trade products. Boycotting has been examined mainly as a single question in a broad inventory of ethical actions [Cowe \& Williams, 2000] or in multinational value surveys [E.S.S. 2002, W.V.S. 2008]. The discursive ethical consumption is the most recently developed type of consumers' action and it has been scantly investigated so far [Micheletti et al., 2005; Stolle \& Micheletti, 2013]. 


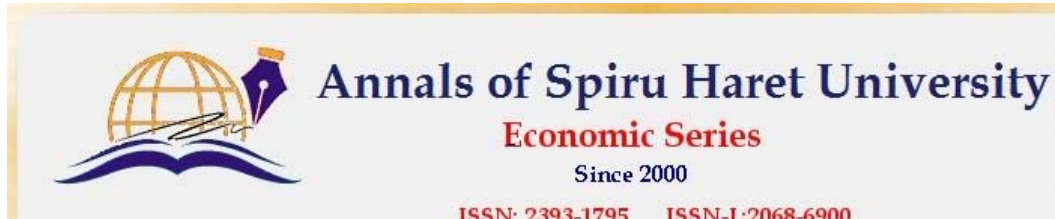

ISSN: 2393-1795 ISSN-I-2068-6900

Issue $3 / 2017$

With reference to the antecedents of behaviour, all relevant efforts incorporated demographics [Klein et al., 2004; Gardberg \& Newburry, 2009; Neilson, 2010; Carr et al., 2012; Delistavrou \& Tilikidou, 2012, Koos, 2012, Carfagna et al., 2014; Copeland, 2014], but the demographical picture of ethical consumers is still a rather ambiguous one. Values or other psychographics have been also utilized, e.g. Inglehart's (1977) materialism/postmaterialism [Pepper et al., 2009; Copeland, 2014], Schwartz's (1992) list of values [Stern et al., 1995; Pepper et al., 2009; Neilson, 2010; Koos, 2012; Delistavrou \& Tilikidou, 2012] and some other politically oriented variables [Neilson, 2010; Koos, 2012; Copeland, 2014], such as locus of control over politics [McCarty \& Shrum, 2001; Tilikidou \& Delistavrou, 2008]. It is to be underlined that surprisingly attitudes seem to be rather absent from the research designs of previous research studies with regards to the aggregate concept of ethical behaviour although attitudinal measures have been always a part of the ecologically oriented consumer research [see among others: Roberts, 1996; Schlegelmilch et al., 1996; Follows \& Jobber, 2000; Fotopoulos \& Krystallis, 2002; Tilikidou \& Delistavrou, 2005 \& 2014].

With regards to the market segmentation, there has been a number of researchers, who have attempted to cluster the market on the basis of fragments of the overall ethical consumption, such as ecological behaviours [Sceepers \& Nellisen, 1989; Nellisen \& Sceepers, 1992; Tilikidou, 2013; Gilg et al., 2005], organics purchasing [Fotopoulos \& Krystallis, 2002] and fair trade products [Delistavrou \& Tilikidou, 2009].

With regards to the overall concept of ethical behaviours, Cowe and Williams (2000), in U.K., identified 5 clusters, namely Do What I Can (49\%), Look after My Own (22\%), Conscientious Consumers (18\%), Global Watchdogs (5\%) and Brand Generation (5\%). Baek (2010), in U.S.A., examined political consumption (boycotting and buycotting) and found 4 clusters, namely Nocotters (55\%), Dualcotters (both boycott and buycott) (22\%), Boycotters (12\%) and Buycotters (10\%).

Concentrating on the characteristic of the above-mentioned segments, it is noticed that the U.K. Watchdogs, found by Cowe and Williams (2000), included middle aged professionals earning higher incomes, who voted for Labour and Green parties and held postmaterialist values. Ten years later in the U.S.A., Baek (2010) found the Dualcotters segment of consumers, who concurrently buycotted and boycotted products for social or ethical reasons. These consumers were found to be white Americans, graduates and post-graduates, earning higher incomes and belonging in the categories either of 26-37 years old or 38-56 years old, which respectively represent the Generation $\mathrm{X}$ or the Baby Boomers (to an extent). 

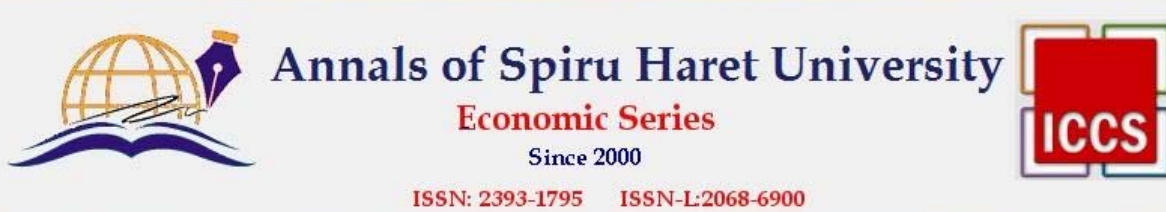

Issue $3 / 2017$

Politically they were liberals, voted for democrats, highly knowledgeable and interested in politics.

\section{Theoretical Perspective and Research Objectives}

The review of the so far relevant knowledge demonstrated considerable voids in order to understand the overall influences and insights that formulate the ethical consumers segment in the market place. In Greece, studies regarding ethical consumption have been definitely scant, so far. Therefore, there is a clear need and importance to explore the potentials of a segmentation scheme on the basis of ethical criteria in this geographical area and describe in - as many details as possible - the profile of ethical consumers.

The above presented literature review illustrated that the profile of Greek ethical consumers should include findings regarding their demographic characteristics plus characteristics that concern their individual differences that have been previously found relevant to this kind of behaviour, namely political sense of control, as well as societally oriented values, such as consumers' relationships with materialism. Of course, the literature review revealed that the main void in this topic has been the absence of attitudes in the so far research designs; thus, there is a definite need to investigate the potential impact of relevant attitudes to the three ethical behaviours under investigation. Consequently, the following research objectives were set:

$>$ to investigate the enhancement level of Greek consumers regarding all three types of ethical consumption;

$>$ to attempt a segmentation of the Greek market on the basis of ethical consumption;

$>$ to investigate the demographic, attitudinal and psychographic characteristics of the ethical consumers' market segment.

\section{Methodology}

\section{Measurement}

For the three (3) behavioural variables (Positive, Negative and Discursive Ethical Consumption) existing in previous academic literature scales were adopted from Delistavrou and Tilikidou (2012) after some necessary amendments.

Positive Ethical Consumption (PEC) consists of 15 items, Negative Ethical Consumption (NEC) has 9 items and Discursive Ethical Consumption (DEC) has 12 items. All behavioural items were measured on a 7-point frequency scale from $1=$ None (Never) to $7=$ All the times (Always). 


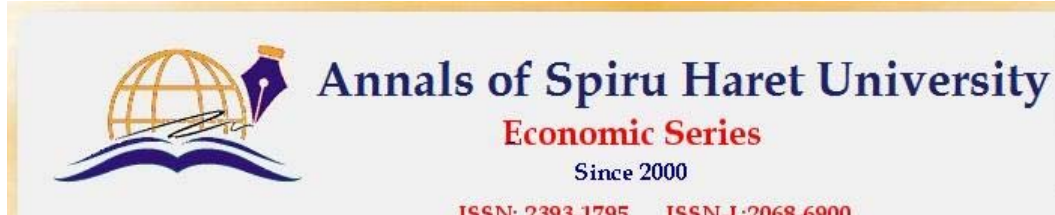

ISSN: 2393-1795 ISSN-I-2068-6900

Issue $3 / 2017$

With regards to the independent variables, as to attitudes, an original measure of negative attitudes to incorporate items that concern not just one but all the three types of Ethical Consumption was constructed, namely the Ethical Unconcern scale. A long measures' development procedure was implemented that followed suggestions by Churchill (1979) and (1995, pp. 543-545), Robinson et al. (1991, pp. 5-14), Spector (1992, pp. 19-46) and Hair et al. (2010) in order to construct a new measure of specific, negative attitudes towards all types of ethical consumption. The final measure of Ethical Unconcern included 19 items; its validation procedure ended in 2 sub-measures, namely Ethical Indifference (with 11 items) and Ethical Scepticism (with 8 items), all measured on a 7-point Likert scale from $1=$ Strongly disagree to $7=$ Strongly agree.

As to demographics, Gender, Age, Education, Income and Occupation were selected to be examined. The scales used by the Hellenic Statistical Authority (H.S.A.) in the Household Budget Surveys (H.S.A., 2014) were adopted.

For the psychographics, two sets of psychographics were selected: the Policy Control sub-scale of the Socio-political Control measure, adopted from Zimmerman \& Zahniser (1991) and the Materialism/Postmaterialism social values scales, adopted from Inglehart (1977). Policy Control consists of 9 items which were all measured on a 7 -point Likert scale from $1=$ Strongly disagree to $7=$ Strongly agree. The measures of Materialism and Postmaterialism, which consist of 6 items each, were measured on a 7-point importance scale from $1=$ Very unimportant to $7=$ Very important. It was considered better to follow Bean \& Papadakis (1994) and Pepper et al. (2009), who had not adopted the original ranking scale but the importance scale, which makes no preliminary discrimination between materialists/postmaterialists in the sample. An extra question was added asking respondents to choose the most important goal for the Greek state among the Materialism and Postmaterialism items.

In an effort to exclude social desirability effects in the examination of Ethical Consumption, Spector (1992, p. 36) was followed and the sub-scale of Communal Impression Management (CIM) was adopted from Blasberg et al. (2014). CIM comprises of 10 items all measured on a True-False scale. CIM refers to the respondents' purposeful tailoring their answers to create the most positive social image [Robinson et al., 1991].

\section{Sampling}

The main survey of this research project was conducted in Thessaloniki, Greece urban area. The population of the survey was defined as all the households 


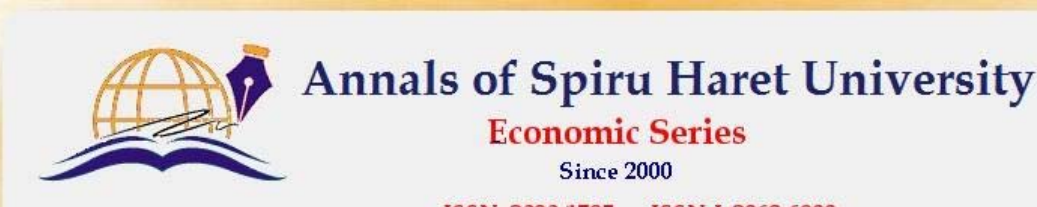

ISSN: 2393-1795 ISSN-L:2068-6900

Issue 3/2017

in the selected geographical area, so the population unit was one household in the Thessaloniki urban area and the sampling unit was an adult member of each household. In total, 440 personal interviews were taken and they provided 420 usable questionnaires.

As to the sampling method, a combination of the two-stage area sampling method together with the stratified method was employed [Tull \& Hawkins, 1993; Zikmund, 1991]. Gender and age population distributions served as the stratifying variables.

\section{Results}

The demographics of the sample (except the stratifying variables) were tested through t-test with regards to the population parameters and no statistically significant differences were found.

\section{Reliability}

All behavioural variables obtained Cronbach's alpha values greater than 0.80 (PEC a $=0.876, \mathrm{NEC} \mathrm{a}=0.957, \mathrm{DEC} \mathrm{a}=0.915)$, which according to Robinson et al. (1991, p. 13) indicate exemplary reliability. The Ethical Unconcern (EthU) measure provided an alpha value of 0.927 , and its sub-measures Ethical Indifference and Ethical Scepticism provided alpha values of 0.910 and 0.869 respectively, which indicate exemplary reliability, too. With regards to the psychographic variables, Policy Control provided an alpha value of 0.736 , which indicates extensive reliability. Materialism and Postmaterialism provided alpha values 0.844 and 0.895 respectively, which indicate exemplary reliability. The Communal Impression Management scale provided a low alpha value of 0.574 , which according to Robinson et al. (1991, p. 13) indicates minimal internal consistency.

\section{Descriptives}

The variable of Positive Ethical Consumption (PEC) takes theoretical values from 15 to 105 and provided a Mean of 44.42 (Std. Dev. $=15.18$ ) indicating that the Greek consumers "Sometimes" engage in PEC. The variable of Negative Ethical Consumption (NEC) takes theoretical values from 9 to 63 and resulted in a Mean of 31.42 (Std. Dev. = 16.92) indicating that the Greek consumers "Sometimes" engage in NEC. The variable of Discursive Ethical Consumption (DEC) takes theoretical values from 12 to 84 and resulted in a Mean of 22.41 (Std. Dev. $=10.82$ ) indicating that the Greek consumers "A few times" undertake the DEC activities. 


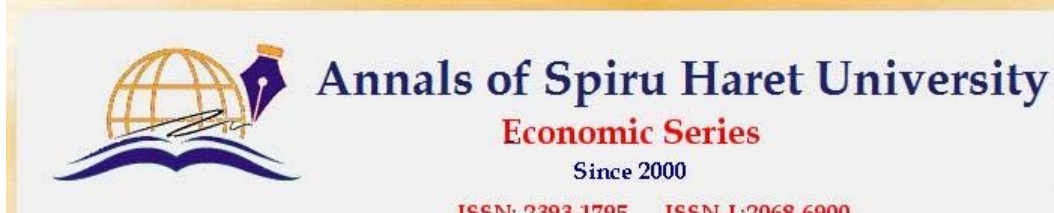

ISSN: 2393-1795 ISSN-L-2068-6900

Issue $3 / 2017$

With regards to Ethical Unconcern, the sub-scale of Ethical Indifference takes theoretical values from 11 to 77 and provided a Mean of $39.19($ Std. Dev. $=14.06)$ indicating that the respondents hold moderate level of Ethical Indifference meaning that they are neither indifferent nor interested in ethical consumption issues. The sub-scale of Ethical Scepticism takes theoretical values from 8 to 56 and provided a Mean of $21.44($ Std. Dev. $=8.70)$ indicating that the respondents hold a low level of Ethical Scepticism, i.e. they do not feel sceptical about ethical consumption issues.

The scale of Policy Control takes theoretical values from 9 to 63 and provided a Mean of 38.36 (Std. Dev. $=8.58$ ) indicating that the respondents hold a moderate level of perceived control over the political and the social systems. The scale of Materialism takes theoretical values from 6 to 42 and resulted in a Mean of 37.18 (Std. Dev. $=5.01$ ) indicating that Greeks consider "Important" the materialist goals in overall. The scale of Postmaterialism takes theoretical values from 6 to 42 and provided a Mean of 36.35 (Std. Dev. $=5.60)$ indicating that Greeks consider "Important" the postmaterialist goals, too. With regard to the most important goal, the frequencies revealed that $55.6 \%$ of the respondents chose materialist goals and the $44.4 \%$ chose a postmaterialist goal. The scale of Communal Impression Management takes theoretical values from 0 to 10 and provided a Mean of 4.05 $($ Std. Dev. $=2.15)$ indicating that the respondents almost moderately faked answers to look good or socially accepted. The scale was coded in a way that higher values indicate high social desirability.

\section{Segmentation}

In an effort to obtain more detailed information with reference to the ethical consumers' segment in the Greek market, the K-means cluster analysis was utilized. The K-means technique classifies cases (respondents not variables) into relatively homogeneous groups [Malhotra, 1999]. The aim is to indicate distinct for each group degree of involvement in the behaviours under examination. In this study, all behavioural items of Positive Ethical Consumption (PEC), Negative Ethical Consumption (NEC/boycotting) and Discursive Ethical Consumption (DEC) were entered in the analysis. In this sense, an aggregated (summated) measure of Ethical Consumption was put under clustering. The most interpretable solution indicated a 4 clusters' specification (Table no. 1).

The first cluster joined together 76 cases $(18.09 \%)$ of those respondents, who obtained the relatively higher cluster centres in almost all items in comparison to their counterparts and thus it was named Ethical Consumers (see Table no. 1). The 

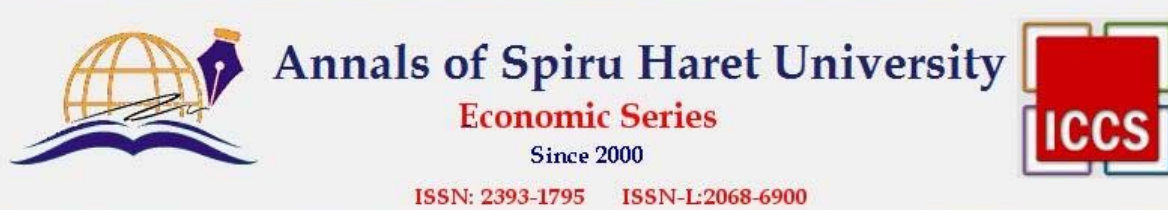

Issue $3 / 2017$

second cluster joined together 86 cases $(20.48 \%)$ of those consumers, who obtained high cluster centres only in the items of Negative Ethical Consumption, namely boycotting and thus it was named Boycotters. The third cluster grouped together 117 cases $(27.86 \%)$ of those consumers, who obtained relatively high cluster centres just in the items of Positive Ethical Consumption, mostly organics, and thus it was named Ecological Consumers. The fourth cluster grouped together 141 cases $(33.57 \%)$, who obtained relatively lower cluster centres in all items and thus it was named Conventional Consumers.

Table no. 1. Ethical Consumption Clusters

\begin{tabular}{|c|c|c|c|c|c|}
\hline All $b$ & havioural Variables & $\begin{array}{c}\text { Ethical } \\
\text { Consumers } \\
76 \text { cases } \\
18.09 \% \\
\end{array}$ & $\begin{array}{c}\text { Boycotters } \\
86 \text { cases } \\
20.48 \% \\
\end{array}$ & \begin{tabular}{c|} 
Ecological \\
Consumers \\
117 cases \\
$27.86 \%$ \\
\end{tabular} & $\begin{array}{c}\text { Conventional } \\
\text { Consumers } \\
141 \text { cases } \\
33.57 \% \\
\end{array}$ \\
\hline & Positi & e Ethical Cor & umption & & \\
\hline $\mathrm{P} 1$ & Buy organic wine & 3.37 & 1.83 & 2.56 & 1.43 \\
\hline $\mathrm{P} 2$ & Buy organic fruit and vegetable & 3.96 & 2.34 & 3.12 & 1.54 \\
\hline P3 & Buy organic honey & 5.29 & 2.76 & 3.86 & 1.64 \\
\hline P4 & Buy organic pasta & 3.49 & 1.51 & 1.99 & 1.15 \\
\hline P5 & Buy organic olive oil & 5.22 & 2.36 & 4.11 & 1.70 \\
\hline P6 & Buy organic milk & 4.16 & 1.79 & 2.54 & 1.33 \\
\hline P7 & Buy organic legumes & 3.86 & 1.85 & 2.04 & 1.12 \\
\hline P8 & Buy organic eggs & 5.36 & 2.42 & 3.91 & 1.61 \\
\hline All $b$ & havioural Variables & $\begin{array}{c}\text { Ethical } \\
\text { Consumers } \\
76 \text { cases } \\
18.09 \% \\
\end{array}$ & $\begin{array}{c}\text { Boycotters } \\
86 \text { cases } \\
20.48 \% \\
\end{array}$ & $\begin{array}{c}\text { Ecological } \\
\text { Consumers } \\
117 \text { cases } \\
27.86 \% \\
\end{array}$ & $\begin{array}{c}\text { Conventional } \\
\text { Consumers } \\
141 \text { cases } \\
33.57 \% \\
\end{array}$ \\
\hline & Positi & e Ethical Cor & umption & & \\
\hline P9 & Buy local traditional food & 4.36 & 3.01 & 4.20 & 2.47 \\
\hline P10 & $\begin{array}{l}\text { Buy products from } \\
\text { underdeveloped countries } \\
\text { delivered via Fair Trade (e.g. } \\
\text { sugar, cocoa, chocolates) }\end{array}$ & 2.09 & 1.72 & 1.28 & 1.13 \\
\hline P11 & $\begin{array}{l}\text { Choose to buy products from } \\
\text { business, which perform socially } \\
\text { responsible activities, too }\end{array}$ & 3.20 & 2.97 & 2.25 & 1.56 \\
\hline P12 & Buy energy efficient bulbs & 5.41 & 4.69 & 5.70 & 4.13 \\
\hline P13 & $\begin{array}{l}\text { Recycle the recyclable } \\
\text { packaging }\end{array}$ & 5.61 & 5.15 & 5.28 & 3.42 \\
\hline P14 & $\begin{array}{l}\text { Use the food containers instead } \\
\text { of throwing them to the rubbish }\end{array}$ & 5.01 & 4.03 & 3.92 & 2.76 \\
\hline
\end{tabular}


Issue $3 / 2017$

\begin{tabular}{|c|c|c|c|c|c|}
\hline P15 & $\begin{array}{l}\text { Repair or maintain used } \\
\text { products instead of replacing } \\
\text { them with new ones (clothes, } \\
\text { furniture, electrical equipment, } \\
\text { linen etc.) }\end{array}$ & 4.09 & 3.93 & 3.97 & 2.67 \\
\hline \multicolumn{6}{|c|}{ Negative Ethical Consumption } \\
\hline N1 & $\begin{array}{l}\text { Seriously damage the } \\
\text { environment }\end{array}$ & 5.07 & 5.36 & 2.79 & 1.79 \\
\hline N2 & $\begin{array}{l}\text { Be involved in financial } \\
\text { scandals }\end{array}$ & 5.09 & 5.09 & 2.19 & 1.52 \\
\hline N3 & $\begin{array}{l}\text { Be involved in safety and } \\
\text { hygiene scandals }\end{array}$ & 5.55 & 5.74 & 3.35 & 2.39 \\
\hline N4 & Use child labour & 5.97 & 5.92 & 2.56 & 1.79 \\
\hline N5 & $\begin{array}{l}\text { Be involved in extremely cruel } \\
\text { behaviour towards animals }\end{array}$ & 5.75 & 5.67 & 2.32 & 1.82 \\
\hline N6 & $\begin{array}{l}\text { Be involved in extremely cruel } \\
\text { behaviour towards workers }\end{array}$ & 5.82 & 5.88 & 2.47 & 1.84 \\
\hline N7 & $\begin{array}{l}\text { Financially support } \\
\text { governments, which are } \\
\text { involved in wars }\end{array}$ & 5.18 & 5.57 & 1.94 & 1.57 \\
\hline N8 & $\begin{array}{l}\text { Support, hostile to our country, } \\
\text { interests }\end{array}$ & 5.76 & 5.70 & 2.70 & 2.07 \\
\hline N9 & $\begin{array}{l}\text { Make profit in an extremely } \\
\text { promiscuous way }\end{array}$ & 5.55 & 5.73 & 2.77 & 1.91 \\
\hline \multicolumn{6}{|c|}{ Discursive Ethical Consumption } \\
\hline D1 & $\begin{array}{l}\text { Discussion with friends and } \\
\text { acquaintances about the 'ethical/ } \\
\text { unethical' practices applied in } \\
\text { the production }\end{array}$ & 3.93 & 3.47 & 3.25 & 2.19 \\
\hline D2 & $\begin{array}{l}\text { Participation in petition } \\
\text { gathering }\end{array}$ & 2.84 & 2.15 & 1.86 & 1.22 \\
\hline D3 & $\begin{array}{l}\text { Spread of messages (emails, } \\
\text { SMSs) }\end{array}$ & 2.87 & 2.17 & 1.92 & 1.29 \\
\hline D4 & $\begin{array}{l}\text { Group-discussions at social } \\
\text { media and forums regarding } \\
\text { ethical consumerism }\end{array}$ & 3.16 & 2.21 & 1.78 & 1.48 \\
\hline D5 & Participation in protest events & 2.72 & 2.13 & 1.75 & 1.18 \\
\hline D6 & $\begin{array}{l}\text { Establishing and organizing } \\
\text { protest groups }\end{array}$ & 1.80 & 1.45 & 1.14 & 1.04 \\
\hline D7 & $\begin{array}{l}\text { Wearing T-shirts, badges, } \\
\text { accessories etc. with printed } \\
\text { messages, against "unethical" } \\
\text { business practices }\end{array}$ & 2.43 & 1.86 & 1.38 & 1.17 \\
\hline
\end{tabular}


Issue $3 / 2017$

\begin{tabular}{|l|l|c|c|c|c|}
\hline D8 & $\begin{array}{l}\text { Being member of organizations, } \\
\text { unions or clubs engaged in } \\
\text { ethical consumption actions }\end{array}$ & 2.39 & 1.94 & 1.33 & 1.09 \\
\hline D9 & Reading and writing in blogs & 3.09 & 2.19 & 2.09 & 1.45 \\
\hline D10 & $\begin{array}{l}\text { Be present at speeches, } \\
\text { discussions or meetings }\end{array}$ & 3.07 & 2.17 & 1.87 & 1.32 \\
\hline D11 & $\begin{array}{l}\text { Use corporate platforms } \\
\text { automated customer service } \\
\text { functions, chat sites, e- } \\
\text { commerce sites) as arena for } \\
\text { ethical consumerism }\end{array}$ & 2.42 & 1.85 & 1.42 & 1.12 \\
\hline D12 & Antibranding demonstrations & 2.39 & 1.93 & 1.44 & 1.13 \\
\hline
\end{tabular}

The Ethical Consumers' cluster represents, as expected, the smaller portion of the sample. However, emphasis was placed in this cluster as it represents the segment of those consumers, who are more frequently involved in ethically influenced choices, regarding not just one type of ethical consumption but the aggregated construct of ethical consumption. The consumers of this cluster adopt all three ethical consumption types more often than their counterparts do. It is to be noted though that not even Ethical Consumers obtained impressively high cluster centres in most of the items (see Table no. 1). More specifically, the cluster centres indicate that Ethical Consumers "Many times" recycled the recyclable packaging (P13). They have also "Many times" during the last year have boycotted firms, which have been accused of child labour (N4), extremely cruel behaviour towards workers (N6) or animals (N5) and of supporting hostile interests to Greece (N8). They have "Several times" boycotted firms, which have been accused of environmental damages (N1), financial (N2) or safety and hygiene scandals (N3) or companies, which supported Governments involved in wars (N7). "Several times" too, they have bought organic eggs (P8), honey (P3) and olive oil (P5), as well as they have used the food containers instead of throwing them to the rubbish (P14). "Almost half of the times" they bought food, they have preferred local traditional food (P9), organic milk (P6), fruit and vegetables (P2), and legumes (P7). "Almost half of the times" they chose to repair a damaged used product instead of replacing it with a new one (P15). Less frequently they have chosen to buy products from socially responsible business, organic wine or pasta and fair-trade products. "Almost half of the times" they have met their friends and acquaintances and they had discussions about "ethical/unethical" business practices (D1). They have been "Sometimes" joining group-discussions at social media and forums regarding 


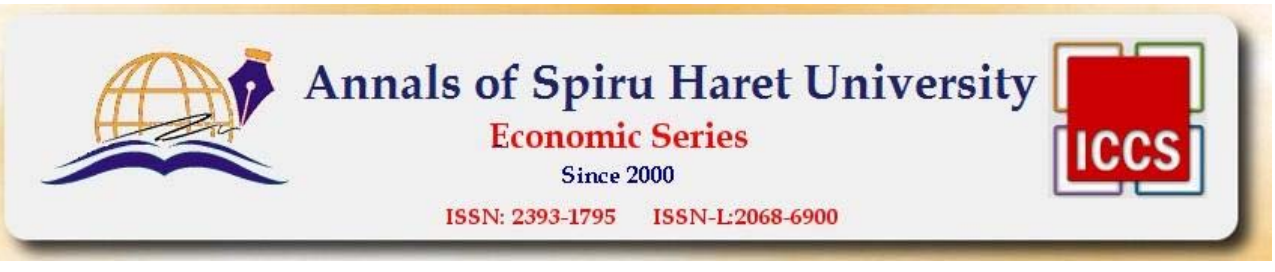

Issue $3 / 2017$

ethical consumerism (D4), reading and writing in blogs (D9) and they have been attending speeches, discussions or meetings (D10). Ethical Consumers have also "Sometimes" spread messages (emails, SMSs) (D3) and participated in petition gatherings (D2) and protest events (D5). Less frequently they have performed the other discursive activities, such as organizing protest groups and/or anti-branding demonstrations (D6, D12).

Further analyses (One-way ANOVA and Pearson's parametric correlations) were conducted within the Ethical Consumers' cluster at an effort to describe those consumers in terms of demographic, attitudinal and psychographic characteristics (Table no. 2).

One-way ANOVA was employed to test the Mean differences of the summated variable of Ethical Consumption (EC) across demographics (Table no. 2). Statistically significant $(\mathrm{p}<0.05)$ Mean differences in EC were found just across education (higher Means were obtained by graduates and post-graduates).

Table no. 2. Profile of Ethical Consumers

\begin{tabular}{|l|c|}
\hline \multicolumn{2}{|c|}{ One-way ANOVA EC (summated) across Demographics } \\
\hline Gender & \\
\hline Age & $\begin{array}{c}\text { Graduate }+ \\
\text { Post-graduate }\end{array}$ \\
\hline Education & \\
\hline Income & \\
\hline Occupation & $-0.263^{* *}$ \\
\hline Partial Correlations Controlled for $\mathbf{S D}$ with EC (summated) \\
\hline Ethical Indifference & $-0.290^{* *}$ \\
\hline Ethical Scepticism & $0.372^{* * *}$ \\
\hline Policy Control & $-0.350^{* *}$ \\
\hline Materialism & \\
\hline Postmaterialism & \\
\hline
\end{tabular}

Correlations between the aggregated Ethical Consumption (EC) and each one of the attitudinal and psychographic scales indicated that Ethical Consumers are primarily influenced by psychographics and to a lesser extent by attitudes (Table 


\section{Issue $3 / 2017$}

no. 2). More specifically, EC was found to be statistically significantly, moderately and positively correlated to Policy Control $(r=0.372, p<0.001)$, negatively to Materialism $(\mathrm{r}=-0.350, \mathrm{p}<0.05)$ and rather weakly and negatively to Ethical Unconcern, both to Ethical Scepticism $(r=-0.290, p<0.05)$ and Ethical Indifference $(r=-0.263, p<0.05)$. Further, One-way ANOVA was employed in order to examine the Mean differences in EC across Materialists/Postmaterialists, namely those, who chose a materialist or those, who chose a postmaterialist goal as their own most important one (Table no. 3). The results indicated that those, who chose a postmaterialist goal as most important, are those who indicated the higher Mean in the summated measure of Ethical Consumption.

Table no. 3. One-way ANOVA in Ethical Consumption across Materialists/Postmaterialists

\begin{tabular}{|ll|ll|r|r|}
\hline \multicolumn{3}{|c|}{$1 . \quad F=6.111$} & \multicolumn{3}{c|}{ Sig. $=0.016$} \\
\hline 2. & & 3. & $N$ & $4 . \quad$ Mean \\
\hline 5. & Materialists & 6. & 40 & $7 . \quad 142.1750$ \\
\hline 8. & Postmaterialists & 9. & 36 & 10. & 153.0833 \\
\hline 11. & Total & 12. & 76 & 13. & 147.3421 \\
\hline
\end{tabular}

\section{Discussion - Limitations - Future Research}

First of all, it has to be underlined that the level of ethical consumption was found at a somehow low degree of engagement. This evidence is consistent with previous research results [e.g. Delistavrou \& Tilikidou, 2012] in the same geographical area; it is also in line to some recent secondary data, which indicated that Greek consumers spend less money for organics, in comparison to other European consumers [FiBL, 2016].

In general, it seems that there is a reluctance of consumers to adopt more frequently the actual purchasing behaviours; this evidence indicates once more that radical behavioural changes are not easily adopted by consumers of a society. This conclusion is in line with previous comments made by many authors, such as Carrigan \& Attalla (2001), Jackson (2005, p. 66), Peattie \& Crane (2006), Pepper et al. (2009), Papaoikonomou et al. (2011) and Tilikidou (2013), among others.

With reference to previous segmentation findings, the results of this study cannot be compared with results of just any segmentation effort that included specific behaviours, for example merely the ecological behaviours; they can be compared only with the results of those previous studies that have attempted 


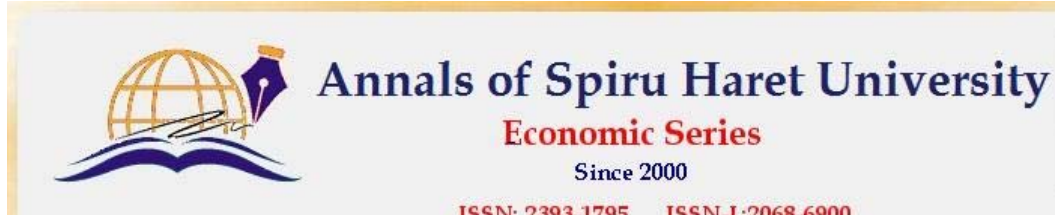

ISSN: 2393-1795 ISSN-I*2068-6900

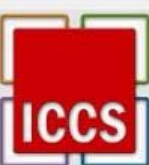

Issue $3 / 2017$

segmentation on the basis of ethical consumption. As mentioned in the literature review, two such studies were located, those by Cowe and Williams (2000) in U.K. and by Baek (2010) in U.S.A. The ethical consumers' segments in those two studies were found around $20 \%$, which is quite similar with the relevant finding of this study. Of course, there is a phase difference time wise, as the Cowe and Williams's (2000) data most probably refer to the end of the nineties while the Baek's (2010) data have been gathered in 2002. This observation indicates the already mentioned delay in the formulation of an ethical segment in the Greek market.

With regards to the demographics of the ethical segment, only education was found able to affect ethical consumers. This result is in line to the results of previous studies [Cowe \& Williams, 2000; Baek, 2010]. The failure to reveal other demographic characteristics is in contrast to the same studies [Cowe \& Williams, 2000; Baek, 2010], which have found that age and income too can discriminate ethical consumers.

With reference to the correlates of the Ethical Consumers' segment, it is to be discussed that Ethical Consumers were found in this study to be mostly motivated by their political views (positively) and by their level of materialism (negatively). These findings indicate that they are politically empowered and active people, being non-materialists at the same time, however without being clearly postmaterialists as Cowe and Williams (2000) had found. The findings that concern politics are somehow in line with those by Baek (2010), who found that Dualcotters (buycotting and boycotting) obtained the higher Means in knowledge and interest in politics.

With regards to the limitations of this study, it is to be noted that this research faced, usual in self-report surveys, the difficulties in measurement accuracy. The analysis of the results was put under control for social desirability (SD) as the measure of Communal Impression Management (CIM) had been included in the questionnaire. The correlation coefficients between pairs of all multi-item measures were all marginally decreased by the control for social desirability. The failure to extensively exclude social desirability from the correlations should most probably be attributed to the inability of the CIM scale. It cannot be asserted by any means that a self-report survey in the Ethical Consumption topic can be free from overestimation. However, it seems that the level of boycotting must have been indeed increased in Greece in comparison to the findings of the European Social Surveys of 2002-3 [Koos, 2012] and 2010 [E.S.S., 2010], which had indicated that less than $10 \%$ of the Greeks had boycotted a product or firm due to ethical, 


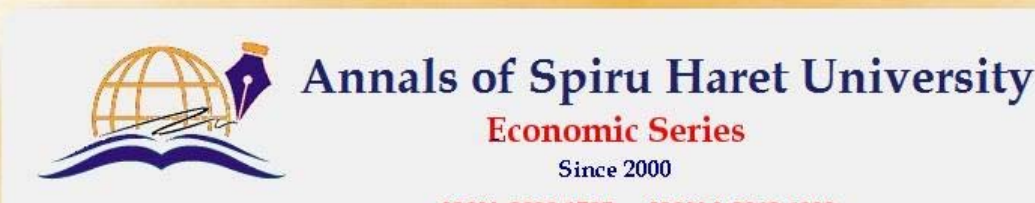

ISSN: 2393-1795 ISSN-L:2068-6900

Issue 3/2017

political or environmental reasons. The increase in boycotting participation might be attributed to a certain campaign that concerns a famous multi-national soda brand name, whose factory was shut down in Greece. Indeed, some latest market reports indicated a considerable increase in the sales of the Greek refreshment producers during the years of economic crisis [Koutifari, 2016]. More specifically, a Market Track by Nielsen indicated that in Thessaloniki, where the boycott campaign has launched in October 2013, the boycotted cola brand had witnessed a decrease in its sale by $14.5 \%$ during August and September 2014 while a Greek cola brand had an increase of $135.3 \%$ in its sales at the same period of time [Gitsi, 2015].

As ethical consumption research by nature focuses on "doing good for the society" [Smith, 1990], an SD effect should be assumed in each and every selfreport survey on the topic. This fact makes the effort to isolate and exclude bias even more difficult and calls for recurrent pilot testing of SD scales and/or other techniques until the most appropriate one for the specific topic, time and place comes into light.

Moreover, there are some weaknesses in the phrasing of the behavioural variables that limited the measurement accuracy. The scale of NEC did not contain a specific item about companies, usually multinationals, big businesses, that are responsible for mass layoffs of workers, which has been an unfortunately customary issue in Greece these days. With relevance to the DEC scale, the choice to develop and employ a thorough multi-item measure to examine this type of behaviour is considered a limitation as there is still a very limited portion of Greeks that take part in these activities. Therefore, future research efforts should examine all three types of ethical consumption by the employment of the adequate measures for the specific context (geographical area, economy, culture etc.). Research efforts should be directed on the improvement of the relevant constructs of PEC, NEC and DEC. More specifically, the scale of NEC should be carefully re-designed to include items that "apply" in the specific context, e.g. to include just the boycott calls running in the specific market at the survey time. With regard to the DEC scale, recurrent qualitative techniques are required to reveal the activities that are taking place in the specific country at present time.

Finally, although this study contributed to our knowledge with regards to a segmentation scheme of the Greek market on the basis of ethical criteria, it is apparent that there is still much ahead of further research with regards to a more detailed profile of ethical consumers, in each country, in Europe and in the world, either in terms of their demographic or social or psychographic characteristics. 


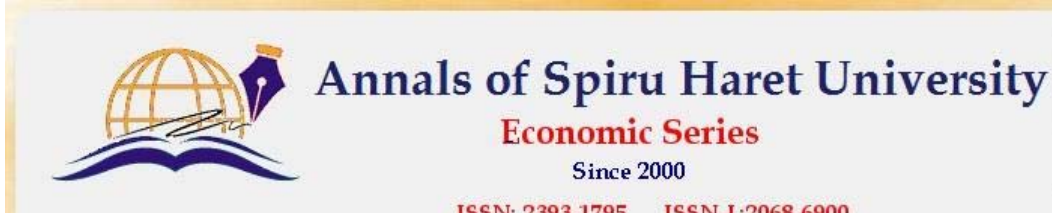

ISSN: 2393-1795 ISSN-L-2068-6900

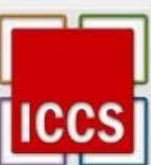

Issue $3 / 2017$

\section{Conclusions and Implications}

The descriptive statistics regarding the whole sample indicated that Greeks are not frequently engaged in ethical consumption behaviours. More specifically, the results indicated that the engagement in positive, as well as in negative ethical consumption, were both below average. The adoption of discursive activities was found to be of even lower frequency.

The attempt to provide the first segmentation scheme of the Greek market on the basis of the overall ethical consumption resulted in 4 segments of the Greek market: the Ethical Consumers (18.09\%), the Boycotters (20.48\%), the Ecological Consumers (27.86\%) and the Conventional Consumers (33.57\%).

It can be concluded that the ethical consumers' segment consists of those graduate and post-graduate citizens, who adopt all ethical behaviours more frequently than their counterparts while they were found to be more confident they can control politics, less materialists, most attracted by a postmaterialist goal for the Greek State, as well as less sceptical towards ethical products and less indifferent about ethical consumption issues.

This segment counting for 1 out of 5 of the sample, even if argued about overestimation due to the effect of social desirability, it can still be considered as a large enough segment, attractive to be targeted and potentially profitable.

Business interesting in adopting an ethically oriented strategy may find useful implications in the results of this study. The findings derived by the examination of the aggregated ethical behaviours, in the first segment, imply that business strategies towards Ethical Consumers should include the expansion of their product lines with organic and local products in recyclable packaging. In addition, they might consider adopting CSR projects. Further, it was revealed that corporations can protect themselves by ethical consumers' boycotting campaigns if they avoid "unethical" business strategies. First of all child labour, cruel behaviour towards workers and animals and environmental damages should be vanished from the customary business practices. Firms should also apply transparent financial practices and obtain safety and hygiene certifications; by no means, they should not support hostile to Greece interests or be involved in wars. Companies could build their "ethical" profile by promoting simultaneously their ethical products and their ethical practices.

The findings with regards to the antecedents of ethical consumption in the Ethical consumers' segment imply that these citizens are strongly likely to be attracted by business offerings that challenge their feelings of contribution to wellfare of the local and the wider society or national economy towards a less materialist and a more postmaterialist state. 


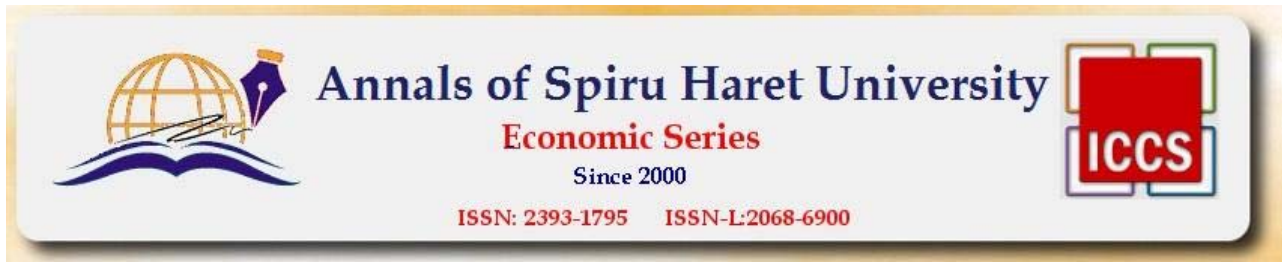

Issue $3 / 2017$

Besides business, groups and associations that aim to facilitate ethical causes, such as environmental protection, human rights, fair trade, etc., may very well find useful implications derived by the results of this study. They should firstly note that their audience is among highly educated consumers. Further, if they need (which they do) to enlarge their target group/s they should create communicative strategies that aim to increase the general public's political empowerment and postmaterialist values while at the same time decrease citizens' materialist values and ethical unconcern, both scepticism and indifference. The higher the perceived policy control and postmaterialism while the lower materialism and ethical unconcern the larger the ethical consumer segment is hopefully going to be.

\section{References}

Baek, Young Min, "To Buy or Not to Buy: Who Are Political Consumers? What Do They Think and How Do They Participate?", Political Studies, 58(5), (2010): 1065-1086.

Bean, Clive \& Elim Papadakis, "Polarized Priorities or Flexible Alternatives? Dimensionality in Inglehart's Materialism-Postmaterialism Scale", International Journal of Public Opinion Research, 6(3), (1994): 264-288.

Blasberg, Sabrina A., Katherine H. Rogers \& Delroy L. Paulhus, "The Bidimensional Impression Management Index (BIMI): Measuring Agentic and Communal Forms of Impression Management", Journal of Personality Assessment, 96(5), (2014): 523-531.

Carfagna, Lindsey B., Emilie A. Dubois, Connor Fitzmaurice, Monique Y. Ouimette, Juliet B. Schor, Margaret Willis \& Thomas Laidley, "An Emerging Eco-Habitus: The Reconfiguration of High Cultural Capital Practices among Ethical Consumers", Journal of Consumer Culture, 14(2), (2014): 158-178.

Carr, Jasun D., Melissa R. Gotlieb, Nam-Jin Lee \& Dhavan V. Shah, "Examining Overconsumption, Competitive Consumption, and Conscious Consumption from 1994 to 2004: Disentangling Cohort and Period Effects", The ANNALS of the American Academy of Political and Social Science, 644(1), (2012): 220-233.

Carrigan, Marylyn \& Ahmad Attalla, "The Myth of The Ethical Consumer - Do Ethics Matter in Purchase Behaviour?", Journal of Consumer Marketing, 18(7), (2001): 560-577.

Carrigan, Marylyn, Isabelle Szmigin \& Joanne Wright, "Shopping for a Better World? An Interpretive Study of the Potential for Ethical Consumption within the Older Market", Journal of Consumer Marketing, 21(6), (2004): 401-417.

Copeland, Lauren, "Value Change and Political Action: Postmaterialism, Political Consumerism, and Political Participation", American Politics Research, 42(2), (2014): 257-282. 


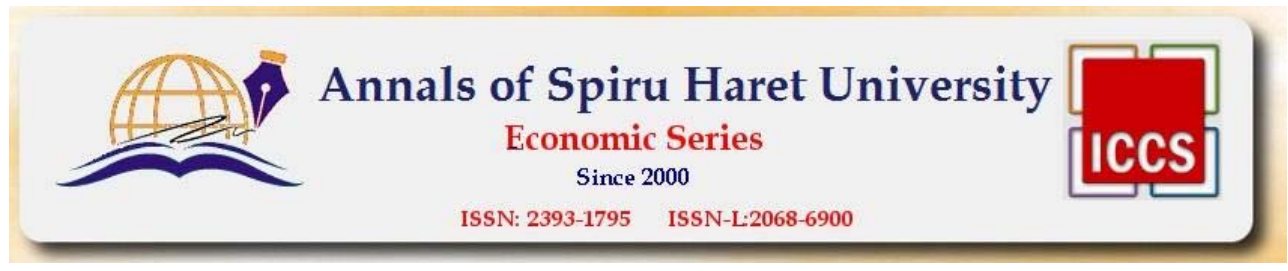

Issue $3 / 2017$

Cowe, Roger \& Simon Williams, "Who Are the Ethical Consumers?", Ethical Consumerism Report, Cooperative Bank (available at: http://www. cooperativebank.co.uk/servlet/Satellite?c=Pageandcid=1139903089615andpagename $=$ CoopBank $\% 2$ FPage $\% 2$ FtplPageStandard).

Delistavrou, Antonia \& Irene Tilikidou, "Are Greeks Ready to Enhance the Fair Trade Market?", Proceedings of the $4^{\text {th }}$ International Conference on Services Management "Managing Services across Continents", Oxford Brookes University, Oxford, 8-9 May 2009, (2009): 203-224.

Delistavrou, Antonia \& Irene Tilikidou, "Exploring the Ethical Behaviour Adopted by Greek Consumers", Journal of Marketing Vistas, 1(2), (2012): 22-35.

E.S.S., Datafile downloaded from: http://www.europeansocialsurvey.org/download.html? file $=\mathrm{ESS} 1 \mathrm{GR} \& \mathrm{c}=\mathrm{GR} \& \mathrm{y}=2002(2002)($ accessed on May 2016).

E.S.S., Datafile downloaded from: http://www.europeansocialsurvey.org/download.html? file $=$ ESS5GR \&c $=$ GR\&y $=2010$ (2010) (accessed on May 2016).

FiBL, "The World of Organic Agriculture: Statistics \& Emerging Trends 2016", (2016), FiBL and IFOAM-Organics International, Frick and Bonn.

Follows, Scott B. \& David Jobber, "Environmentally Responsible Purchase Behaviour: A Test of a Consumer Model", European Journal of Marketing, 34(5/6), (2000):723746.

Fotopoulos, Christos \& Athanasios Krystallis, "Purchasing Motives and Profile of the Greek Organic Consumer: A Countrywide Survey", British Food Journal, 104(9), (2002): 730-765

Gardberg, Naomi A. \& William Newburry, "Who Boycotts Whom? Marginalization, Company Knowledge, and Strategic Issues”, Business \& Society, 52(2), (2009): 318357.

Gilg, Andrew, Stewart Barr \& Nicholas Ford, "Green Consumption or Sustainable Lifestyles? Identifying the Sustainable Consumer", Futures, 37(6), (2005): 481-504.

Gitsi, Alexandra, "Refreshments: Decreases of the Multinational brands' Market Shares", available at: http://www.euro2day.gr/news/economy/article/1290829/anapsyktikaxethymainei-to-anthrakiko-ton-polyethniko.html (2015) (accessed on May 2016).

H.S.A., "Household Budget Survey: Final Quality Report", (2014), Athens: Hellenic Statistical Authority.

Harrison, Rob, Terry Newholm \& Deirdre Shaw, The Ethical Consumer (London: Sage, 2005).

Inglehart, Ronald, The Silent Revolution: Changing Values and Political Styles among Western Publics (Princeton, NJ: Princeton University Press, 2005).

Jackson, Tim, Motivating Sustainable Consumption: A Review of Evidence on Consumer Behaviour and Behavioural Change, report to the Sustainable Development Research Network (S.D.R.N.), (2005), Surrey UK: S.D.R.N. 


\section{Issue $3 / 2017$}

Klein, Jill Gabrielle, Craig N. Smith \& Andrew John, "Why We Boycott: Consumer Motivations for Boycott Participation", Journal of Marketing, 68(3), (2004): 92-109.

Koos, Sebastian, "What Drives Political Consumption in Europe? A Multi-Level Analysis on Individual Characteristics, Opportunity Structures and Globalization", Acta Sociologica, 55(1), (2012): 37-57.

Koutifari, Eugenia, "Juices-Refreshments: Innovation, Value for Money and Brand Name are the Factors of Superiority", available at: http://www.marketingweek.gr/ default.asp?pid=9\&la=1\&arId=58757 (2016) (accessed on May 2016).

McCarty, John A. \& L. J. Shrum, "The Influence of Individualism, Collectivism, and Locus of Control on Environmental Beliefs and Behaviour", Journal of Public Policy \& Marketing, 20(1), (2001): 93-104.

Micheletti, Michele, Dietlind Stolle, Laura Nishikawa \& Matthew Wright, "A Case of Discursive Political Consumerism: The Nike E-Mail Exchange", in Proceedings of the $2^{\text {nd }}$ International Seminar on Political Consumerism, Oslo, 26-29 August 2004, Oslo, Norway: TemaNord, (2005): 255-290.

Neilson, Lisa A., "Boycott or Buycott? Understanding Political Consumerism", Journal of Consumer Behaviour, 9(3), (2010): 214-227.

Nellisen, Nico \& Peer Sceepers, "Business Strategy and Environment: The Need for Information about Environmental Consciousness and Behaviour", Business Strategy and the Environment, 1(2), (1992): 13-23.

Papaoikonomou, Eleni, Gerard Ryan \& Matias Ginieis, "Towards a Holistic Approach of the Attitude Behaviour Gap in Ethical Consumer Behaviours: Empirical Evidence from Spain", International Advances in Economic Research, 17(1), (2011):77-88.

Peattie, Ken \& Andrew Crane, "Green Marketing: Legend, Myth, Farce or Prophesy?", Qualitative Market Research: An International Journal, 8(4), (2006): 357-370.

Pepper, Miriam, Tim Jackson \& David Uzzell, "An Examination of the Values that Motivate Socially Conscious and Frugal Consumer Behaviours", International Journal of Consumer Studies, 33(2), (2009): 126-136.

Roberts, James A., "Green Consumers in the 1990s: Profile and Implications for Advertising", Journal of Business Research, 36(3), (1996): 217-231.

Robinson, John P., Phillip D. Shaver \& Lawrence S. Wrightsman, Measures of Personality and Social Psychological Attitudes (San Diego, CA: Academic Press, 1991).

Scheepers, Peer \& Nico Nelissen, "Environmental Consciousness in the Netherlands", Netherlands Journal of Housing and Environmental Research, 4(3), (1989): 199-216.

Schlegelmilch, Bobo B., Greg M. Bohlen \& Adamantios Diamantopoulos, "The Link Between Green Purchasing Decisions and Measures of Environmental Consciousness", European Journal of Marketing, 30(5), (1996): 35-55.

Spector, Paul E., "Summated Rating Scale Construction: An Introduction", in Quantitative Applications in the Social Sciences, series no. 07-082., Michael S. Lewis-Beck ed., Newbury Park, CA: Sage Publications, Inc. 1992. 


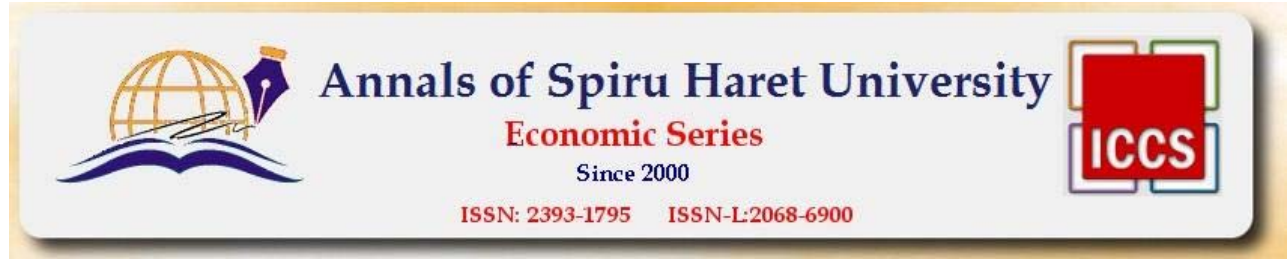

Issue $3 / 2017$

Stern, Paul C., Linda Kalof, Thomas Dietz \& Gregory A. Guagnano, "Values, Beliefs, and Pro-environmental Action: Attitude Formation toward Emergent Attitude Objects", Journal of Applied Social Psychology, 25(18), (1995): 1611-1636.

Stolle, Dietlind \& Michele Micheletti, Political Consumerism: Global Responsibility in Action (New York, NY: Cambridge University Press 2013).

Tallontire, Anne, Erdenechimeg Rentsendorj \& Mick Bowfield, "Ethical Consumers and Ethical Trade: A Review of Current Literature", Policy Series 12, Chatham, UK: Natural Resources Institute 2001.

Tilikidou, Irene, "Evolutions in the Ecologically Conscious Consumer Behaviour in Greece", Euromed Journal of Business, 8(1), (2013): 17-35.

Tilikidou, Irene \& Antonia Delistavrou, "Pro-environmental Purchasing Behavior: the Inhibiting Influence of the Materialistic Values", in: Ziamou P. and Zotos Y. (Eds.), Proceedings of the $9^{\text {th }}$ International Conference on Marketing and Development, Marketing Contributions to Prosperity and Peace, Thessaloniki GR: International Society of Marketing and Development 2005.

Tilikidou, Irene \& Antonia Delistavrou, "Pro-Environmental Purchasing Behaviour during the Years of Economic Crisis", Marketing Intelligence and Planning, 32(2), (2014): 160-73.

Tilikidou, Irene \& Antonia Delistavrou, "Types and Influential Factors of the Consumers' Non-purchasing Ecological Behaviours", Business Strategy and the Environment, 17(1), (2008): 61-76

Tilikidou, Irene, "Ecologically Conscious Consumer Behaviour in Thessaloniki, Greece", unpublished doctoral dissertation, University of Sunderland, U.K. 2001.

Tull, Donald S. \& Dell I. Hawkins, Marketing Research, sixth edition (New York, NY: McMillan, 1993).

W.V.S., "World Value Survey 2008", available at: http://www.europeanvaluesstudy.eu/page/ survey-2008.html (2008), (accessed on May 2016).

Zikmund, William G., Exploring Marketing Research, fourth edition (Orlando: The Dryden Press, 1991).

Zimmerman, Marc A. \& James H. Zahniser, "Refinements of Sphere-Specific Measures of Perceived Control: Development of a Socio-political Control Scale", Journal of Community Psychology, 19(2), (1991): 189-204. 
